\title{
Importance of Ideological and Political Education in Teaching Fine Arts Education in Higher Vocational Colleges
}

\author{
Bizhu Lin* \\ Quanzhou Arts and Crafts Vocational College, Quanzhou 362500, Fujian Province, China
}

\begin{abstract}
Ideological and political education is the fundamental way to implement the goal of establishing moral value and educating students in local higher vocational colleges. For teaching fine arts education in higher vocational colleges, ideological and political education is rationally taught to fully instill the thoughts contained in art disciplines. Political elements, organically integrates ideological and political education with academic art education to form an educational synergy and promote the professional and ideological growth of students. Based on the analysis of the importance of integrating ideological and political education in the teaching of fine arts in higher vocational colleges, this research proposes several implementation methods, hoping to provide help to promote the orderly development of national higher education.
\end{abstract}

Keywords: Curriculum education; Art teaching; Importance; Effective ways

Publication date: May, 2021; Publication online: 31 May, 2021

*Corresponding author: Bizhu Lin, j678678@163.com

\section{Introduction}

As the main subject of an art major in higher vocational colleges, the improvement of art teaching quality can effectively promote the improvement of students' cultural and artistic accomplishment and develop artistic expressions. In the process of enhancing the education improvements of "double first-class" colleges and universities, higher vocational colleges are paying more attention to the integration of ideological and political education in the development of art teaching. For art students, the improvement of their professional ability is inseparable from art education, but the effect of ideological and political education affects their internal development. Therefore, it is of great significance to explore the importance of ideological and political education in teaching art in higher vocational colleges. Xiao Baojun $^{[1]}$ pointed out that ideology educational is a comprehensive educational concept used to achieve the educational goal of establishing moral values in colleges and universities. Ideology and political education should be infused into art education and teaching activities, whereby it should be fully utilized through meticulous teaching design. The ideological and political educational elements are combined with teaching activities to achieve the natural integration of ideological and political teaching and subject education. In daily teaching activities, the main moral values in the ideological and political courses are subtly integrated into the art theory. This is to promote "ideological and political" and "art" in weak students and allow them to grow into new social talents with strong comprehensive abilities. This article is based on teaching methods combined with the summary of art teaching experiences, and discusses some opinions on the importance of integrating ideological and political education into art teaching in higher vocational colleges as well as the methods of integration, hoping to provide reference for relevant art teachers. 
2 Importance of Ideological and Political Education in Teaching Fine Arts in Higher Vocational Colleges

Necessary integration of ideological and political education in art lessons allows to guide students to establish the correct "three views." With the further enhancement of the local higher education, it has become an inevitable trend to integrate ideological and political teaching into art education, which is also an inherited demand for art talent training. At the symposium of teachers and students at Peking University, General Secretary Xi emphasized the importance of art education. He pointed out that art is not only the clarion call for the advancement of the times, but also represents the style of the times. Art education in higher vocational colleges is not only the teaching of art knowledge and painting skills but also an enhancer of students' ideological and political quality. While enhancing their artistic accomplishments, it also establishes students firm professional confidence and the correct "three views."

\subsection{Necessary integration of ideological and political education in teaching art encourages students to form correct attitude and values}

The professional behavior of art students in many higher vocational colleges is taught by art education teachers. They are the builders and successors of the national art education in the future. Therefore, the values they established during their university years are not only directly related to the future of the students they will teach, but also to the state of physical and mental health related to the rapid achievement of the "Chinese Dream."

Considering the overall quality of students in many local higher vocational colleges, most of them show positive, healthy, and upward spiritual qualities. However, due to the impact of Western culture in the social media era, moral values of many students are affected as they are easily diverted. Thus, if they are not guided properly, many students will easily lose themselves in this multi-culturalistic environment. As a result, students would lose the traditional virtues of the Chinese nation and a sense of responsibility and mission, and their thinking would become polluted. However, if the ideological and political education is properly integrated into art education, thus the students can be influenced by art in a subtle way and shape a healthy personality in a positive way as well as form a correct mind set. During art education, teachers actively guide students to establish correct artistic and creative concepts, guide students to seek the truth and be sensible, as well as achieve natural innovation when inheriting Chinese traditional culture, thereby forming correct socialist core values.

\subsection{Necessary integration of ideological and political education in teaching art promote the overall improvement of students' quality}

Based on the fundamentals of the new education enhancements, the education goal of contemporary higher vocational colleges is to train high-quality talents for the country and the society. Contrarily, affected by the traditional education method, the fine arts majors in higher vocational colleges used to focus on professional education with a complete neglect of the improvement of students humanistic literacy. Although ideological and political education are leveled with professional education, he standards are not the same. Therefore, with the introduction of the concept of ideological and political education in higher vocational colleges, it has made up for the lack of despising the development of the humanistic quality of students in the past. Additionally, the combination of ideological and political education in art education not only enriches students' artistic experience, but also enables them to gain artistic awareness and develop moral values. Thus, the substantial improvement has fully promoted the overall development of students, and the rational integration of ideological and political teaching in art education can greatly enhance the cultural connotation of art professional courses and perfectly combine the flexibility of art disciplines with the diligence of the ideological and political education. Finally, the combination of art and ideology infuses and compliments each other and mutually promote the overall improvement of 
college students' comprehensive quality ${ }^{[2]}$.

\section{Effective Ways of Integrating Ideological and Political Education into Art Education in Higher Vocational colleges}

\subsection{Psychological guidance in art class}

In the process of integrating ideological and political education into art education, we must first establish a teaching environment for ideological and political education and select one or two outstanding students as role models, so that they can play an exemplary role and lead the students to develop toward the established ideological and political education thinking. At the same time, a efficient reward and punishment system should be established to commend students who have performed well and made progress, while those who deviate from the goal of ideological and political education will be given certain punishments but the punishment is not the real purpose, whereby it aims to guide them toward the right development path. When necessary, providing psychological counseling and comfort to weak students so that they can regain their confidence in learning, enhance their interest in learning, and enhance their artistic ability ${ }^{[3]}$.

\subsection{Giving full attention to the role of teaching materials}

The 5,000-year history of civilization, patriotism, solidarity and mutual assistance, hard work, courage, and self-improvement are the qualities that every good son and daughter of China hopes to possess. A student who possesses these qualities will always be patriotic no matter where they are in the future. However, these beautiful qualities are not innate to a person as they are gradually formed through experience and lessons as well as accumulated over time under the influence of role models. Therefore, teachers must give full attention to the important role of teaching materials, whereby students can distinguish right from wrong and good from bad when appreciating art. Additionally, the development of these good qualities through teaching materials allows them find the direction of their efforts in practice, as well as to be humble when achieving their goals and brave when facing struggles.

\subsection{Actively carrying out art-related activities} In addition to art education and teaching activities, teachers actively carry out some art-related activities that are of great value in this era, whereby students can learn art, develop spirituality, and channel art when participating in activities. Through excellent artworks, students can be greatly encouraged which benefits their personal qualities. For example, when students participate in art exhibitions, they have an amount of imagination after watching many colorful works of art. Similarly, they tend to be inspired to be able to link life and art together and allowing them to understand the connection between art and life. Through similar valuable art activities, students ideological realm, values, and artistic consciousness will surely be further enhanced, thereby strengthening their confidence in studying art and strengthening their confidence in becoming useful people in society.

\subsection{Carrying out artistic social service activities} While conducting art lessons, teachers should encourage students to enter the society and participate in the group art interactive activities. This is to strengthen the connection with the society and promote their own sense of social responsibility as well as the sense of life goals. For instance, students participate in social activities to be able to understand the local peoples conditions and transform the political and ideological concepts and moral values developed in school into their own values, thereby promoting the development of other good behaviors and habits. During social service activities, the school encourages students to participate in voluntary service activities, study well in the "community university," and fully develop into useful people. In addition, schools should lead students to visit the Red Mark cities to gain a deep and practical understanding of local life, feel the artistic atmosphere and understand the patriotism of the ancestors in order to establish correct life values and enhance their own ideology, 
moral values and patriotic feelings ${ }^{[4]}$.

\subsection{Creating a strong artistic environment on campus}

In the process integrating ideological and political education into art education, we must first do a good job in the construction of campus culture. For example, create a strong cultural and artistic environment on the campus to ensure the smooth development of ideological and political education because the environment is a key factor that stimulates a person's interest in learning. Furthermore, if higher vocational colleges can build a strong artistic environment on campus in a beautiful manner, the students can improve their thinking and standardize behavior under continuous artistic influence. At the same time, they can also learn independently, gain experience and further grow their skills. Additionally, it is not difficult to create an artistic environment on campus. For instance, conducting art festivals, art competitions and other related activities can create a strong artistic environment. Also, through participating in various forms of artistic activities, students' interest in learning can be further enhanced, encouraging them to participate in activities with greater enthusiasm, enhance their own life-style and strengthen their own cultural heritage.

\section{Conclusion}

The education of higher vocational colleges, art education and ideological and political education are closely related; specifically, they complement and influence each other. Therefore, in order to ensure the improvement of students' overall quality, ideological and political teaching should be integrated into the art education to ensure that the distinctive concept of patriotism construction infuses into the minds of students through artistic academic teaching so that students ideological quality and academic level are further improved. In 2018, General Secretary Xi Jinping mentioned in his reply to an old professor at Central Academy of Fine Arts: "In strengthening the work of artistic education, first of all, we must adhere to the moral values, encourage people, believe in succeeding in life, follow the characteristics of artistic education, promote the spirit of Chinese artistic education and promote the healthy growth of the young generation." At this stage, the practices of ideological and political education in higher vocational colleges are progressing smoothly and has achieved good results, but the implementation of ideological and political education still needs to be further improved. Based on the fundamentals of "double first-class" construction, higher vocational colleges must thoroughly prioritize the importance of ideological and political education in art education. This integration of ideological and political education into art education and teaching provides necessary psychological guidance in the classroom through teachers whereby they conduct artistic service activities such as creating a strong campus artistic environment and other effective ways to achieve the goal of art education as well as promoting the initial meaning of the reform goals of China's higher education,

\section{Disclosure statement}

The author discloses no conflict of interest.

\section{References}

[1]Xiao, B., Zhang, Q., Wang. X(2020). The Reform Dimension of Art Teaching from the Perspective of Curriculum Ideology and Politics- Taking the Preschool Education Major of Higher Vocational Education as an Example. Popular Literature and Art,(11):25.

[2]Lian, C(2019). Research on the Integration of Art Teaching into Ideological and Political Education Mechanism in Colleges and Universities under the Background of "Double First-Class." Education and Teaching Forum,(03):20.

[3]Huang, S(2021). Research on the Implementation Path of "Curriculum Ideology" in Art Teaching in Normal Universities. Beauty and Times (Medium),(01):15.

[4]Ding, Y(2020). Moral Education Thoughts in Chinese Traditional Art Education and Its Enlightenment. Art Grand View, (1):122-123. 